\title{
Student Team Achievement Divisions (STAD) Technique through the Moodle to Enhance Learning Achievement
}

\author{
Monchai Tiantong ${ }^{1} \&$ Sanit Teemuangsai ${ }^{2}$ \\ ${ }^{1}$ Faculty of Technical Education, KMUTNB, Bangkok, Thailand \\ ${ }^{2}$ Faculty of education, Rajabhat Maha Sarakham University, Maha Sarakham, Thailand \\ Correspondence: Monchai Tiantong, Faculty of Technical Education, King Mongkut's University of Technology \\ North Bangkok, 1518 Pracharat 1 Road, Bangsue, Bangkok 10800, Thailand. Tel: 66-2555-2000. E-mail: \\ monchai@kmutnb.ac.th
}

Received: February 20, 2013 Accepted: March 1, 2013 Online Published: March 12, 2013

doi:10.5539/ies.v6n4p85 URL: http://dx.doi.org/10.5539/ies.v6n4p85

\begin{abstract}
One of the benefits of using collaborative learning is enhancing learning achievement and increasing social skills, and the second benefits is as the more students work together in collaborative groups, the more they understand, retain, and feel better about themselves and their peers, moreover working together in a collaborative environment encourages student responsibility for learning. This paper presents the results of an application of the student team achievement divisions technique through the modular object oriented dynamic learning environment (Moodle) to enhance learning achievement on computer programming course. The sample group were twenty students divided into four small groups. The experimental course was computer programming for undergraduate students using ADDIE instructional model for developing, that consisted of five steps: analysis, design, development, implementation, and evaluation. The collaborative learning module consisted of student profile management, group management, communication, scaffolding, learning activities, learning progress, portfolio, learning resources, quiz, evaluation, and learning report. The findings revealed that the learning achievement of the pretest scores are found to be significantly different from the posttest ones at the .05 level, and the efficiency value of the lesson was at 83.05/80.40 according to the E1/E2 formula, which was higher than the determined value of $80 / 80$. In conclusion, the student team achievement divisions technique can be applied through the Moodle to enhance learning achievement on computer programming course successfully.
\end{abstract}

Keyword: student team achievement divisions (STAD), scaffolding, modular object oriented dynamic learning environment (Moodle), ADDIE instructional model, the E1/E2 formula

\section{Introduction}

\subsection{Background Information and Problem Statement}

Education is the essential core to push the country securely to the next century and the quality of the education needs to be realized. Studying directly from the teacher through memorizing and focusing only on the course contents cannot develop students in all aspects. Thus, children and young people have not yet been developed to their full potentials and have not cultivated the desired characteristics such as curiosity, analysis thinking, logical solution, disciplines and honesty. Moreover, teachers usually give lectures focusing on the contents and the subjects, but not the students. This kind of teaching cannot help students learn to face problems and solve them in their real lives (The Office of the National Education Committee, 2002). Good teaching and learning needs to be able to draw more students' attention, serve different groups of students, and emphasizes more on skill practice, thinking process and situational management. Particularly in the framework for 21 st Century Skills, that learning consists of core subjects and themes that revolve around three core skills: life and career skills, learning and innovation skills, and information media, and technology skills. These are the skills that students need in order to be successful in the 21 st century, therefore the students have diverse backgrounds, a variety of achievement levels, and different learning styles which will all affect their ability to acquire knowledge, that teachers need to prepare students for the jobs that have not yet been created, for the new products that have not yet been invented, and for the new skills to build towards creativity and innovation (Trilling \& Fadel, 2009). 
In term of collaborative learning, it emerges from active learning as a method that develops critical thinking and problem-solving skills, both areas of weakness in educational environments (Box, 1986; Boyer, 1987, Ocker \& Yaverbaum, 2004). Collaboration is said to occur when individuals interact with others and exercise, verify, solidify, and improve mental models through both discussion and information sharing (Leidner \& Jarvenpaa, 1995). Traditionally, collaboration has occurred between face-to-face, synchronous groups of students. With telecommunications technology, collaborative experiences can now include anytime/anyplace (Ocker \& Yaverbaum, 2004). Moreover, collaborative learning is an appropriate way to solve such problem because it tends to motivate learners to learn to work together with friends to meet the course objectives. Learners will learn to do different types of activities in smaller groups, such as negotiations, conversations, exchanging ideas in groups or open learning that gives them more opportunities to search for, discover and find answers to existing problems (McAlphine, 2000). Collaborative efforts among students result in a higher degree of accomplishment by all participants as opposed to individual, competitive systems in which many students are left behind (Slavin \& Tanner, 1979). Competition fosters a win-lose situation where superior students reap all rewards and recognition and mediocre or low-achieving students reap none. In contrast everyone benefits from a collaborative learning environment. Students help each other and in doing so build a supportive community which raises the performance level of each member (Kagan, 1986). This in turn leads to higher self esteem in all students (Webb, 1982), and also fosters a higher level of performance by students. Their critical thinking skills increase and their retention of information and interest in the subject matter improves. When students are successful they view the subject matter with a very positive attitude because their self esteem is enhanced. This creates a positive cycle of good performance building higher self esteem which in turn leads to more interest in the subject and higher performance yield. Students share their success with their groups, thus enhancing both the individual's and the group's self esteem. Some collaborative learning structures formalize this effect by awarding certificates of achievement or improvement to students, or extra credit to groups for an individual's or group's improvement (Kulik \& Kulik, 1979). Group members realize that each member's efforts benefit not only himself/herself, but all other group members as well. Jacobs (2006) asserts that positive interdependence is a perception among group members that what helps one group member helps all, and what hurts one group member hurts all (Jacob, 2006).

Using telecommunications technology such as computer network can enable students to collaborate on course assignments and projects outside of classroom, without having to meet face-to-face. This asynchronous learning environment seems to be an especially good match with the profile of many college students. As of 1993, nearly $25 \%$ of all college students had full-time jobs. As of $1995,44 \%$ of students were at least 25 years old, $54 \%$ were working either full or part-time, and $43 \%$ were attending school on a part-time basis. Today, less than one out of six undergraduate students can be considered a traditional college student, one who is between the ages of eighteen and twenty two, attends school on a full-time basis, and lives on-campus (Levine \& Cureton, 1998). Additionally, all part-time graduate students also fit the profile of the nontraditional student. As the benefits of the computer network, it is a lot more efficient at present. It is, therefore, applied more often as an instrument to develop and support the learning and teaching process, which is really useful for learners. It is not necessary for any more for the learners to study only the lessons from a textbook, but they can study from any other sources, thus increasing more varieties of learning. Several challenges have been observed in developing the learning and teaching through the computer network in order to support interactive learning without being in the same location or at the same time. This results in building more thinking relationships in people, supporting them to learn to work together, reducing limitations of time, locations and participants, and being able to apply varieties of supporting instruments. Even though learning over the computer network offers several advantages, some students still confront problems like failure in cooperating due to individual differences and distinct attitudes. In this situation, learners may not be confident nor interested in joining activities and may come with negative attitudes, thus bringing about unsuccessful teaching and learning. The way to solve this problem is to arrange the environment to suit the learners' conditions, teaching techniques and efficient teaching and learning technology.

\subsection{Student Team Achievement Divisions (STAD)}

STAD stands for student team achievement divisions, it is a collaborative learning strategy in which small groups of learners with different levels of ability work together to accomplish a shared learning goal. It was devised by Robert Slavin and his associates at Johns Hopkins University (Innovative Learning, 2009), students are assigned to four or five member learning teams that are mixed in performance level, gender, and ethnicity. The teacher presents a lesson, and then students work together within their teams to make sure that all team members have mastered the lesson. Finally, all students take individual quizzes on the material, at which time they may not help one another. Students' quiz scores are compared to their own past averages, and points are 
awarded on the basis of the degree to which students meet or exceed their own earlier performance. These points are then summed to form team scores as in Figure 1, and teams that meet certain criteria may earn certificates or other rewards. In a related method called teams-games-tournaments (TGT), students play games with members of other teams to add points to their team scores. STAD and TGT have been used in a wide variety of subjects, from mathematics to language arts to social studies, and have been used from second grade through college. The STAD method is most appropriate for teaching well-defined objectives with single right answers, such as mathematical computations and applications, language usage and mechanics, geography and map skills, and science facts and concepts. However, it can easily be adapted for use with less well-defined objectives by incorporating more open-ended assessments, such as essays or performances (Adesoji \& Ibraheem, 2009).

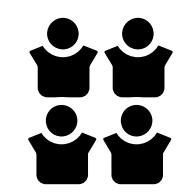

1. Learn together

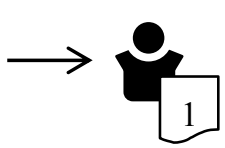

2. Take individual quizzes

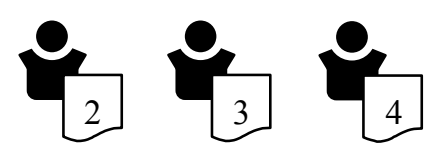

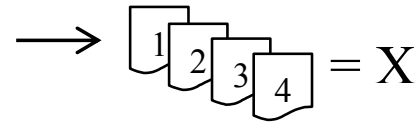

3. Sum to group scores

Figure 1. Student team achievement divisions (STAD) technique

In term of learning achievement using the STAD, a study of Keramati (2009), entitled "The effect of cooperative learning on academic achievement of physics course", it is found that experimental group students taught by cooperative learning (STAD technique) are more successful than control group students. At this point, it is found that cooperative learning increased academic achievement of students to a higher level when compared to conventional teaching method (Keramati, 2009), similarly, a study of Yu (1998), it is found that subject in the cooperation tended to have higher scores on both the posttest and questionnaire measuring attitudes toward science course (Yu, 1998).

\subsection{Moodle}

Moodle (abbreviation for modular object oriented dynamic learning environment) is the content management system (CMS) or usually known as the learning management system (LMS) or the virtual learning environment (VLE). It is the open source system that is really suitable to be applied in writing very flexible and efficient online lessons. A lot of users apply this system in more than eighty languages and more than two hundred countries. The Moodle consists of the following supporting sections: curriculum management section, instrument management section, module management section, lesson management section and previewing lesson management section. It is suitable for students to use as an instrument in designing the online lessons which are highly flexible and efficient with ease of use of the Moodle enabling regular updating of links/materials. Teacher could edit/add new links in lessons, immediately as they are suggested by students, to provide an ordered list of course requirements (Couteur, 2007). In a study of Adams et al. (2009), they asserts that the Moodle has evolved into a visually and socially customizable platform. In other words, the Moodle is built to accept a wide variety of plug-in modules, a multitude of functionalities and can be pieced together to create a unique case-specific version of the course management system. The plug-in modules range from providing smart academic calendars, social activity interfaces and grade management, to incorporating E-commerce applications as well as a wide array of other possibilities (Adam et al, 2009).

\subsection{The Collaborative Problem-Based Learning (PBL) Model}

This model in Figure 2, was obtained from the opinion survey of the experts using the Delphi technique. The model consists of eight modules as shown in Figure 2, as follows: 1) problem-based learning (PBL) module, this is the main part of the model that provides problems or situation to the students, 2) student module, this connects to PBL, knowledge, collaborative, scaffolding, and assessment module, 3) collaborative module, this provides collaborative learning techniques for group learning, 4) communication module, this provides communication tools for group learning, 5) knowledge module, this provides an effective information for students to complete their tasks, 6) coaching module, this module coaches the students as a reviewer, director, monitor, facilitator, and evaluator, 7) assessment module, this is to evaluate the learning progression of the student, and 8) scaffolding module, this is designed to promote a deeper learning for students (Teemuangsai \& Tiantong, 2008). 


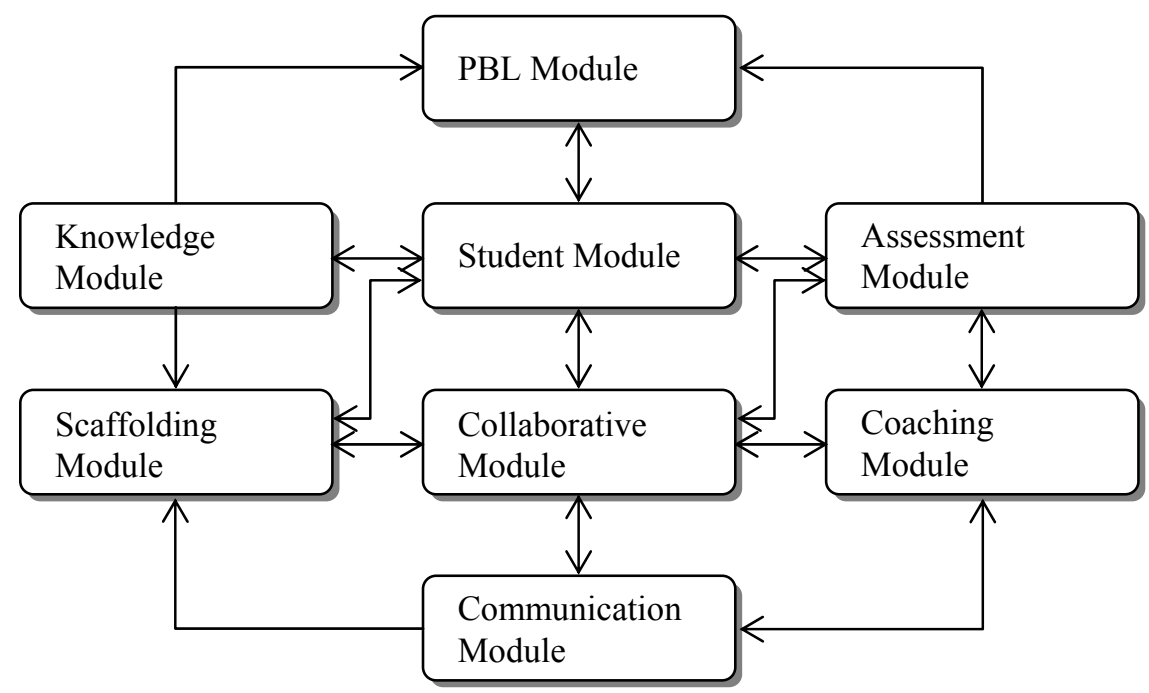

Figure 2. Components of the collaborative problem-based learning model from Delphi technique

For these reasons, the authors were interested in studying and developing the collaborative learning through the computer network using the student team achievement divisions technique through the Moodle, which is open source and ready-made with no extra costs. This would also save time and budget in developing a new system and provide the ability to try applications according to the collaborative learning system. Later, this collaborative learning system would be included in the collaborative problem-based learning model (Teemuangsai \& Tiantong, 2008) through the computer network developed by the authors. Thus, the aims of this paper was to study the application of the student team achievement divisions technique through the Moodle to enhance learning achievement on computer programming courses. The expectations of the findings of this study that can be applied the student team achievement divisions technique through the Moodle to enhance learning achievement on computer programming course.

\section{Method}

\subsection{The Research Procedure}

The research procedure followed the five steps of the ADDIE instructional model (Clark, 2004), as follows: 1) A - Analysis, the first step was to determine the course curriculum, target learners, mission and objectives, 2) D Design, the next step was to design the structure of the lessons, the lessons themselves, activities and assessment, information sources, grouping organization and collaborative learning techniques, 3) D - Development, at this stage, the lessons were developed and added with activities, tests and learning resources, based on the Moodle. Further developments included learners' information management, portfolios, communications, scaffoldings, follow-ups and learning evaluation, 4) I - Implementation, this step was to divide the learners into small groups, prepare the location and train learners to learn to tryout the lessons, and 5) E - Evaluation, the research instruments were evaluated by the experts and the small group pilot. The final step was to make a conclusion and do the presentation.

\subsection{Population and Sample Group}

The sample group was from the first year undergraduate students in the computer science area, Rajabhat Maha Sarakham University. The study then applied the simple random sampling to select a section of twenty students divided into four small groups, to be the sample group of this study.

\subsection{Research Tools}

The research tools in this study was the online collaborative problem-based learning lesson through the Moodle that consists of:

1) The online collaborative problem-based learning lesson on computer programming for undergraduate student.

2) The pretest, quizzes, and posttest.

Unfortunately, there are a few limitations to this study. Firstly, the size of the sample group was only twenty undergraduate students. This could be corrected in future work by increasing the number participates to 50 or 
more. Secondly, the STAD technique is still a relatively new approach and will take time to become more familiar to teachers and students.

\section{Results}

\subsection{The Collaborative Learning System Using The STAD Technique on the Moodle}

The developed system consists of eleven parts as follows: 1) Learner information management, this part allows learners to register, $\log$ on and edit their personal information, 2) Learner grouping organization, this part, teacher can suitably group students based on the average scores of the previous learning. The scores are ordered from high to low (good $>$ weak), but they are assigned into the group one by one, 3) Communications, it consists of the bulletin board, Q\&A web board, teacher consultation and chat. Teacher can give marks for exchanging learning or for students' interests, 4) Learner assistance, the lesson module of the Moodle was employed as the learning scaffolding with these four models: conceptual, metacognitive, strategy, and procedure, 5) Learning activity organization, this part is separated into nine units in similar order. Each unit consists of the objectives, learning sources, problem situations, scaffolding, portfolios, activity schedule and tests, 6) Progress report, this part is used as the follow-up section to check the learners' progress. Teachers can give suggestions and mark their students' work in this section as well, 7) Portfolios, this is a workshop module of the Moodle is used to collect the learners' portfolios and the teachers can set up the criteria in evaluating different parts of the portfolios, 8) Learning sources, this part, there are web lessons, e-books, teaching slides, and learning sources on the web sites, 9) Quizzes, this part is used to write the tests in separate study units and objectives, which are easy for randomizing the test questions, 10) Evaluation, the evaluation process consists of the marking of the learning exchange and collaboration. The marks will then be ordered and given bonus points based on the performance of the learner group, and 11) Achievement report, the report keeps the records of assignment status, weekly scoring sheets, honoring and award-winning of the learner group that can finish the activities as expected.

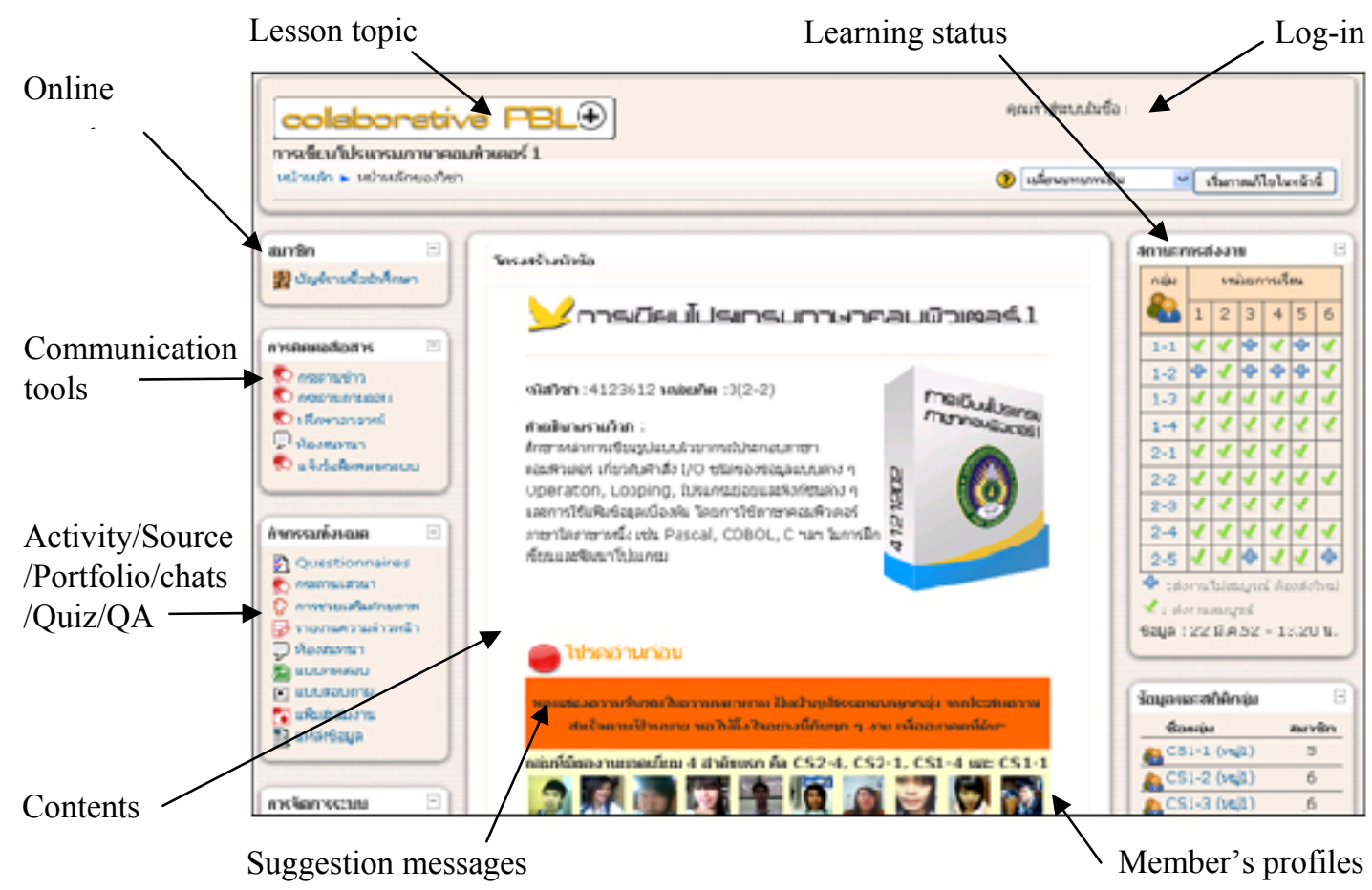

Figure 3. The computer programming lesson (in Thai) on collaborative learning system using the STAD technique through the Moodle 


\subsection{The Evaluation Results of the Developed System}

3.2.1 The Learning Achievement of Twenty Undergraduate Students Divided into Four Small Groups Who Attended the Computer Programming Course through the Developed System is Shown in Table 1

Table 1. The results of pretest, quizzes, and posttest of learning achievement

\begin{tabular}{|c|c|c|c|c|c|c|c|c|c|c|c|}
\hline \multirow{3}{*}{$\begin{array}{l}\text { Groups } \\
(\mathrm{n}=\mathbf{2 0})\end{array}$} & \multirow{3}{*}{$\begin{array}{c}\text { Pretes } \\
\text { t } \\
(50)\end{array}$} & \multicolumn{9}{|c|}{ Quizzes (90) } & \multirow{3}{*}{$\begin{array}{c}\text { Posttest } \\
\text { (50) }\end{array}$} \\
\hline & & No & No & No & No & No & No & No & No & No & \\
\hline & & 1 & 2 & 3 & 4 & 5 & 6 & 7 & 8 & 9 & \\
\hline \multicolumn{12}{|l|}{ STAD Group I } \\
\hline 1. Student I-1 & 32 & 7 & 8 & 10 & 10 & 8 & 7 & 10 & 8 & 10 & 43 \\
\hline 2. Student I-2 & 30 & 7 & 8 & 9 & 10 & 8 & 6 & 10 & 7 & 10 & 40 \\
\hline 3. Student I-3 & 30 & 7 & 8 & 9 & 9 & 8 & 6 & 10 & 6 & 9 & 42 \\
\hline 4. Student I-4 & 31 & 8 & 9 & 9 & 9 & 7 & 9 & 9 & 8 & 6 & 42 \\
\hline 5. Student I-5 & 32 & 8 & 7 & 9 & 8 & 9 & 9 & 7 & 9 & 6 & 40 \\
\hline Group I average scores & - & 7.4 & 8 & 9.2 & 9.2 & 8 & 7.4 & 9.2 & 7.6 & 8.2 & - \\
\hline \multicolumn{12}{|l|}{ STAD Group II } \\
\hline 1. Student II-1 & 29 & 7 & 6 & 10 & 9 & 8 & 5 & 10 & 10 & 9 & 43 \\
\hline 2. Student II-2 & 29 & 8 & 6 & 10 & 10 & 8 & 8 & 10 & 10 & 9 & 45 \\
\hline 3. Student II-3 & 30 & 9 & 7 & 10 & 10 & 9 & 7 & 9 & 9 & 9 & 41 \\
\hline 4. Student II-4 & 27 & 8 & 7 & 9 & 10 & 7 & 7 & 8 & 9 & 9 & 39 \\
\hline 5. Student II-5 & 28 & 7 & 8 & 8 & 9 & 8 & 7 & 10 & 9 & 8 & 33 \\
\hline Group II average scores & - & 7.8 & 6.8 & 9.4 & 9.6 & 8 & 6.8 & 9.4 & 9.4 & 8.8 & - \\
\hline \multicolumn{12}{|l|}{ STAD Group III } \\
\hline 1. Student III-1 & 25 & 7 & 6 & 10 & 9 & 8 & 5 & 9 & 8 & 9 & 38 \\
\hline 2. Student III-2 & 25 & 7 & 6 & 10 & 9 & 8 & 5 & 10 & 8 & 9 & 36 \\
\hline 3. Student III-3 & 24 & 8 & 7 & 10 & 10 & 8 & 8 & 10 & 9 & 9 & 40 \\
\hline 4. Student III-4 & 30 & 8 & 7 & 10 & 10 & 8 & 8 & 10 & 10 & 10 & 42 \\
\hline 5. Student III-5 & 29 & 7 & 7 & 8 & 8 & 9 & 8 & 10 & 10 & 10 & 41 \\
\hline Group III average scores & - & 7.4 & 6.6 & 9.6 & 9.2 & 8.2 & 6.8 & 9.8 & 9 & 9.4 & - \\
\hline \multicolumn{12}{|l|}{ STAD Group IV } \\
\hline 1. Student IV-1 & 32 & 7 & 6 & 10 & 9 & 9 & 7 & 10 & 9 & 10 & 42 \\
\hline 2. Student IV-2 & 29 & 8 & 9 & 9 & 7 & 7 & 5 & 10 & 6 & 9 & 42 \\
\hline 3. Student IV-3 & 25 & 6 & 9 & 10 & 7 & 9 & 4 & 8 & 9 & 7 & 41 \\
\hline 4. Student IV-4 & 22 & 7 & 4 & 10 & 10 & 8 & 8 & 10 & 10 & 10 & 39 \\
\hline 5. Student IV-5 & 26 & 8 & 7 & 9 & 9 & 7 & 9 & 8 & 8 & 6 & 35 \\
\hline Group IV average scores & - & 7.2 & 7 & 9.6 & 8.4 & 8 & 6.6 & 9.2 & 8.4 & 8.4 & - \\
\hline Total average scores & 28.25 & 7.45 & 7.1 & 9.45 & 9.1 & 8.05 & 6.9 & 9.4 & 8.6 & 8.7 & 40.2 \\
\hline Total quizzes scores & - & & & & & 74.75 & & & & & - \\
\hline
\end{tabular}

In Table 1, the total average scores of the pretest is 28.25 and those of the posttest are 40.20 . After the t-test analysis, the $t$ value is 11.26 , which is higher than the set value. Therefore, the pretest scores are found to be significantly different from the posttest ones at the .05 level. 
3.2.2 The Efficiency of the Lesson was Calculated from the Quiz Scores of the Students during the Course and Those in the Posttest. The Scores Obtained were Analyzed and Compared Using the Event1/Event2 (E1/E2) Formula of the Determined Value as 80/80 (Bramawong, 1993), and Shown in Percentage in Table 2

Table 2. The evaluate of the efficiency value of the developed lesson

\begin{tabular}{ccccc}
\hline No. of students & $\begin{array}{c}\text { Average scores during } \\
\text { the course } \\
\text { (quizzes No.1-9) }\end{array}$ & $\begin{array}{c}\text { Average scores in the } \\
\text { posttest }\end{array}$ & E1 (\%) & E2 (\%) \\
\hline \multirow{2}{*}{20} & 74.75 & 40.2 & $\begin{array}{l}(74.75 / 90)^{*} 100 \\
=83.05\end{array}$ & $\begin{array}{l}(40.2 / 50)^{*} 100 \\
=80.40\end{array}$ \\
\hline
\end{tabular}

In Table 2, the efficiency value of the lesson was found to meet the determined value of $80 / 80$. It can be concluded that the lesson was efficient at the value of $83.05 / 80.40$ according to the E1/E2 formula, which was higher than the determined value.

\section{Conclusion and Discussion}

Although the learning management system is an important tool that supports high quality educational experiences, particularly in teaching and learning through the computer network, such e-learning and online lessons, there are also a lot of other open source LMS that may fit requirements and values. Moreover there are limitations of these LMS, some LMS are not reliable, no qualified support available, not compatible with other applications and techniques, etc. Thus, this study intends to develop a collaborative learning system using the student team achievement divisions (STAD) technique with Moodle to enhance learning achievement of undergraduate students who enrolled in computer programming courses, and to evaluate the efficiency of the developed lesson using the E1/E2 formula. Because the Moodle is a popular open source software, so the application of the student team achievement divisions technique through the Moodle to enhance learning achievement is valuable to study, particularly for using in collaborative learning with the problem-based learning. Because collaborative learning with problem-based learning exhibits a higher level of academic achievement, a deeper understanding of learned material, more positive and supportive relationships with peers, and better critical thinking skills and problem solving skills, (Goodsell, 1992; Astin, 1993). These are necessary skills to be good at programming of the student in computer science area.

In this study, the sample groups were twenty undergraduate students divided into four small groups of learners participating in the study. The course of the study was computer programming in the computer science area. The findings show the Moodle was really applicable to develop and organize the collaborative learning activities using the student team achievement divisions technique to enhance the learning achievement successfully. Moreover the students really enjoyed working together through the Moodle with the student team achievement divisions technique, this can be verified empirically by the benefits of the Moodle as a development tool to create the collaborative lesson with problem-based learning over the computer network successfully.

\section{References}

Adams, W. K. (2009). Student Engagement and Learning with PhET Interactuve Simulations. Proceedings of Multimedia in Physics Teaching and Learning.

Adesoji, F. A., \& Ibraheem, T. L. (2009). Effect of student teams achievement divisions And mathematic Knowledge on learning outcomes in chemical kinetics. The Journal of International Social Research, 2(6), 15-16.

Astin, A.W. (1993). What matters in college: Four critical years revisited. San Francisco, CA: Jossey-Bass.

Bok, D. (1986). Higher learning. Cambridge, MA: Harvard University.

Boyer, E. L. (1987). Toward school-college collaboration. Thought and Action, 3(2), 7-18.

Bramawong, C. (1993). A collective course of technology and educational media and education and human resources. Bangkok, Sukhothaithammathirat University.

Clark, D. (2004). History of knowledge, ISD, learning, and management. Retrieved May 12, 2011, from http://www.skagitwatershed.org/ donclark/history_isd/addie.html 
Couteur, L. R. (2007). Computer in the classroom. King Edward VI Grammar School, Chelmsford, Essex, England.

Goodsell, A. S., Maher, M. R., \& Tinto, V. (Eds.). (1992). Collaborative learning: A sourcebook for higher education. National Center on Postsecondary Teaching, Learning, \& Assessment, Syracuse University.

Innovative Learning. (2009). Student team achievement divisions. Retrieved May 9, 2012, from http://www.innovativelearning/learning/cooperative_learning.html

Jacobs, G. (2006). Cooperative Learning and Second Language Teaching. Cambridge University Press.

Kagan, S. (1986). Cooperative learning and sociological factors in schooling, in Beyond language: Social and cultural factors in schooling language minority students. Los Angeles, CA: California State University Evaluation, Dissemination and Assessment Center.

Keramati, M. (2009). The Effect of Cooperative Learning On Academic Achievement of Physics Course. In T. Bastiaens et al. (Eds.), Proceedings of World Conference on E-Learning in Corporate, Government, Healthcare, and Higher Education 2009 (pp. 2751-2756). Chesapeake, VA: AACE.

Kulik, J. A., \& Kulik, C. L. (1979). College Teaching. In Peterson and Walberg (Eds.), Research in Teaching: Concepts, findings and implications. Berkeley, CA: McCutcheon Publishing.

Leidner, D., \& Jarvenpaa, S. (1995). The use of information technology to enhance management school education: A theoretical view. MIS Quarterly, 19(3), 265-291. http://dx.doi.org/10.2307/249596

Levine, A., \& Cureton, J. S. (1998). When hope and fear collide: A portrait of today's college student. San Francisco: Jossey-Bass.

McAlphine, L. (2000). Collaborative Learning Online. Journal of Distance Learning Education, 21(1), 66-80. http://dx.doi.org/10.1080/0158791000210105

Ocker, R. J., \& Yaverbaum, G. J. (2004). Collaborative Learning Environments: Exploring Student Attitudes and Satisfaction in Face-to-Face and Asynchronous Computer Conferencing Settings. Journal of Interactive Learning Research, 15(4), 427-448. Norfolk, VA: AACE.

Slavin, R. E., \& Tanner, A. M. (1979). Effects of cooperative reward structures and individual accountability in productivity and learning. Journal of Educational Research, 72(5), 294-298.

Teemuangsai, T., \& Tiantong, M. (2008). The Collaborative Problem-Based Learning Model through the Computer Network. Proceedings of the 4th National Conference on Computer and Information Technology, (May 23-24, 2008), King Mongkut's University of Technology North Bangkok, Bangkok, Thailand, 179-182.

The Office of the National Education Committee. (2002). The National Education Plan (2002-2016). Bangkok, Thailand.

Trilling, B., \& Fadel, C. (2009). 21st century skills: Learning for life in our times. San Francisco, CA: Jossey-Bass. Retrieved May 5, 2011, from http://www.21stcenturyskillsbook.com/index.php

Webb, N. M. (1982). Group composition, group interaction and achievement in small groups. Journal of Educational Psychology, 74(4), 475-484. http://dx.doi.org/10.1037/0022-0663.74.4.475

Yu, F. Y. (1998). The Effects of Cooperation With Inter-Group Competition on Performance and Attitudes in a Computer-Assisted Science Instruction. Journal of Computers in Mathematics and Science Teaching, 17(4), 381-395. Charlottesville, VA: AACE. 